\title{
Logos Ethos and Pathos in Political Discourse
}

\author{
Tamar Mshvenieradze \\ Faculty of Arts and Sciences, Ilia State University, Tbilisi, Georgia
}

\begin{abstract}
Given article aims at underlining all linguistic means out of the discourses of 2002 and 2007 presidential candidates Jacques Chirac and Nicolas Sarkozy that served as the Triad of Aristotle argumentation - Logos, Ethos, and Pathos - without which it is impossible to build any type of argumentative written, verbal, and/or as in our case, political discourses.
\end{abstract}

Index Terms - argumentation, Logos, Ethos, Pathos, political discourse

\section{INTRODUCTION}

The goal of the given article is to study the phenomenon of the three elements of argumentative persuasion: Logos, Ethos, and Pathos and to reveal the linguistic means used in French political discourses for this purposes.

Research components of the study are the argumentative political discourses such as the pre-election campaign discourses presented by Jacques Chirac and Nicolas Sarkozy to the large audience of electorate. By examining of the discourses we will try to highlight the linguistic means, which are used by each politician to present the three dimensions of the argumentative persuasion - Logos, Ethos and Pathos. In addition we aim at comparing the discourses of the abovementioned presidential candidates to find out how each of them build rationale and logical discourses; how they present own personality; what methods do they appeal to impact electorate emotionally; and finally which out of the three argumentative persuasion means is the most favorite one for each of them or which of them they mostly appeal.

Any type of argumentation is an attempt to impact on interlocutors, to persuade them that the thesis of a speaker (writer) is valid, and to make them to be engaged in the activities in speaker's (writer's) favor. Logos, Ethos and Pathos are inevitable components of reasoning but the combination of all of them enables a speaker successfully complete his/her discourse and achieve his/her goal.

As it is known political discourse is a specific subject of interdisciplinary study and of the sciences such as political science, sociology, psychology, socio-linguistics and other. As we have already mentioned above in the given paper we plan to review such discourse for the purpose of examining the Triad - Logos, Ethos and Pathos - as inevitable components of the Argumentation processes.

\section{CONCEPTS}

As we are aware Greek Philospher Aristotle was the one who wrote one of the most important works on rhetoric in 4th century b.c. after Sophists. He named the work as "Rhetorica". The gretest scientist proved that the rhetoric method was the "art of persuation" thus "the ability, in each particular case, to see the available means of persuasion.". Persuation always means to prove something. According to French linguist, Michel Meyer said rhetoric is "the analyses of connection of means and goals by help of discourse (Meyer, 1996, p.22). Thus we can say that argumentative discourse is appealed in every activity of the human being, where they deal with decision-making and sharing, or acceptance of ideas.

Starting from Aristotle (4th century b.c.) to Chain Perelman (Second part of the 20th century a.d.) analyses of argumentation in discourses, or in other words argumentative analyses aim at describing and explaining of all those means and methods, by help of which the discourse of a writer or a speaker endeavors to impact on audience (Amossy, 2000, p.1). Thus the paper studies the force of word, internal consistency of the message in a specific communication situation, where it is exclaimed or in the other words, in specific institutional, social and cultural strata.

The goal of argumentative writing is to persuade an audience that the ideas of a writer are valid, or more valid than someone else's. It consists of three important inevitable components: Logos, Ethos, and Pathos. For the first time the three elements of argumentation were presented by Aristotle.

Argumentation is effective when a speaker or writer manages to back up his or her claims in a way to impact on readers to change their opinion and make them act in writer's (reader's) favor. Argumentation is not a demonstration to dictate one's will. Speaker needs inductive and deductive proofs to defend own thesis, to convince interlocutors and to impact on them (Dokhturishvili, 2005).

Logos is a very important for argumentative judgment as one of the dimensions of persuasion. Logos means persuading by the use of reasoning which includes critical cognition, analytical skills, good memory, and purposeful behavior, which is the most important argumentation. For Aristotle Logos is rationale, logical and argumentative discourse. 
As to the Ethos, it means convincing by the character of an orator (speaker), which leads to persuasion (according to Chain Perelman orator is the one who exclaims verbal discourse and even the one who does it in the written way). Ethos is a style of a speaker by help of which he or she appeals to and tries to attract the attention of audience to earn their faith. Ethos refers to the trustworthiness or credibility of the writer or speaker. If the speaker is persuasive the audience follows him or her. In his discourse Aristotle calls Ethos the face of the orator which would impact on audience by words, in other words it is a "face created by the discourse". This is conditioned by the fact that the orator earns the credibility only in case if his or her arguments are competent, reliable, fair and frank. Also, argumentation is successful when it appeals to the audience with solidarity, engagement and goodwill (Amossy, 2000, p.60-62).

The impact of ethos is often called the argument's 'ethical appeal' or the 'appeal from credibility. French linguist Dominique Maingueneau, describes Ethos as follows: "Orator's Ethos is related with his/her speech and the role that corresponds to his/her discourse but not the individual" (Maingueneau, 1993, p.66).

We need to say that we tend to believe people whom we respect, someone who is likable and worthy of respect. Ethos is composed of correct attitudes, respect, favor and which is very important, ethics. Thanks to this component of argumentation discourse becomes much more persuasive. According to Ruth Amossy (second part of $20^{\text {th }}$ century) one of the most popular scientists and linguists, there are two types of Ethos: Preliminary Ethos and Discourse Ethos. Preliminary Ethos is what the audience preliminary knows about the speaker (writer), in other words, what it knows about speaker's authority, marital status and social status. Some orators attempt to ground on it and use such Ethos in his/her favor during a discourse, in case if it is positive. But in case if the Preliminary Ethos is negative the speaker does his/her best to revoke such an impression of people on him/her. As to the Discourse Ethos, it is the Ethos created immediately for the specific situation and during the discourse (Amossy, 2000, p.63).

Pathos is directly linked with an audience. Audience is a collective subject of speakers on which an orator tries to impact by own argumentation. Thus having audience is one of the necessary conditions for communication. In Aristotle's book « Rhetoric» Pathos is the power with which the writer's (speaker's) message moves the audience to his or her desirable emotional action. Thus a good orator should know for sure which emotion would effectively impact on audience considering their social status, age and other features. It is important to know not only how the orator can express but how he or she can by help of discourse cause favorable emotions, like anger, insult, empathy, fear, confusion, etc. (Amossy, 2000, p.178).

As it is known, one of the chapters of Aristotle's book named "Book II" is dedicated to the topic, which reviews emotions in three aspects: in which condition the audience experiences emotion, towards which categories they are sensitive and what is its motivation. Summarizing the abovementioned topic we need to say that knowing people's emotions tremendously facilitates us to act with words, to earn their credibility and faith.

Pre-election campaign discourse differs from other discourses by the following: during pre-election periods the discourses of politicians and the disposition of their personality are the subjects of the greatest attention. Presidential candidates should persuade electorate in validity of his/her position and make the audience to move to his/her favorite decision or action for supporting the candidate in future. Politician has as more chance to win elections as argumentative and persuasive is his/her discourse. According to Patrick Charaudeau "to impact on audience with words means change its existing mental status" (Charaudeau, 2005, p.16). That is why in pre-election period every politician absolutely tends to use argumentation, or in other words, as Aristotle says, different strategies of the art of persuasion to achieve the favorite goal. For achieving the goal an orator should take into account and consider the values, opinions and faith of the audience to which he/she appeals to. Thus argumentative discourse is always conditioned socially and culturally.

\section{CORPUS AND RESEARCH}

As we have mentioned above, we have selected as a corpus for research the pre-election discourses presented by Jacques Chirac, the presidential candidate of 2002 elections and Nicolas Sarkozy, the presidential candidate of 2007 elections to the wide audience of electorate in France. The first discourse took place in the city of Afghan and the second one in Nice, France. We looked for the French language materials on an official website - www.elysee.fr

Nowadays political discourse is very urgent and polyhedral phenomenon and is a subject for study and research for many scientists. We mostly review it from the linguistic point of view in the given article. In particular we analyze the linguistic methods, which are used by politicians to convey the three components of argumentation - Logos, Ethos and Pathos. On the first stage of the study we separately analyzed the discourses of Jacques Chirac and Nikolas Sarkozy. We performed lexico-metric analyses which considered statistical examination of the corpus. We also made discourse and argumentative analyses in result of which we highlighted linguistic markers characteristic for each politician which from their side once and for all serve to conveying of Logos, Ethos and Pathos. Finally we compared those two discourses and the linguistic markers used by the authors to view what was the difference and the resemblance between them.

Among the linguistic markers that consist of grammatical and Stylistic units construction the discourses from the point of view of argumentation we have highlighted as follows: Deictic (indexical) words: Personal pronouns - " $I$ ", first person, singular; "We", first person, plural; Possessive pronouns - "My", first person, singular; "Ours" - first person, plural; and the indefinite pronoun "one"; In addition: Rhetoric question and stylistic techniques: revision; comparison; 
citing; allusion and irony. Also we need to mention phrases expressing feelings, addressing and the words phrases describing common values.

Thus the given article aims at revealing how often each abovementioned politician convey the Logos in his discourse, or in other words to see in how logical, rational, critical and analytical way they respond to existing plural problems. We also review how effectively the orator presents himself; impacts on audience; and appeals to its emotions.

According to Jean-Michel Adam, one of the greatest scientists: "Argumentative effectiveness is not defined by own self, it is the process of selecting corresponding attitudes and words for argumentation, and the search for the form of discourse. [...] The form of discourse speech indicates to the coherence and the unity of speakers own values and ideology" (Adam, 2011, p.101-102).

In the city of Afghan, France, the pre-election discourse presented by the presidential candidate Jaques Chirac is constructed as a logical and persuasive speech. The politician dearly conveys plural problems related with environment and pollution, and the reasons causing them all over the world. In result he analyses actual data and informs people on future plans of the Government, which is part of his campaign and considers the strategies of overcoming of all existing problems by help of participation and support of the population. The speaker uses different linguistic means for his purpose to persuade the audience (the mentioned linguistic means will be discussed below). His discourse is logical as he uses linguistic links such as: initially, later and finally. Make use of such types of links is important for argumentative discourse of any type. According to Amossy: "Linguistic links are directly connected with argumentative analyses as to the linking function argumentative linking is added" (Amossy, 2000, p.159).

Like the discourse of Jacques Chirac the pre-election discourse presented by Nicolas Sarkozy in Nice is constructed in logical and persuasive way. But his speech is much more extensive and combined with the elements that signify the Ethos of the orator, there are many methods expressing Pathos as well though. During the whole discourse Sarkozy underlines his advantages against the other party representatives referring to differing views by which he tends to persuade the electorate in his expertise and thus them to vote for him. In addition Sarkozy reveals all those problems which the whole France and the French people are worried about. They are the problems of the young generation, social security, etc. He presents to the electorate some methods of problem solution, which is the main component of his presidential program.

Jacques Chirac appeals to different linguistic means including Ethos for better presenting his personality. First of all we have to underline that this presidential candidate uses singular first person pronoun "I" less (50\%) than plural first person pronoun "we" (70\%) as a deictic. As to the singular possessive first person pronoun "my" deictic, he never uses it. Still we come across to the plural possessive first person pronoun "our" as a deictic in his discourse quite often.

Deictic is a grammatical unit that has a linguistic function. According to Dominique Maingeneau deictic is an adjective relating to, or denoting a word or expression the meaning of which is dependent on the context in which it is used (Maingeneau, 2006, p. 22-23). In our case we should take into account the situation in which the discourse speech was presented and note that the first person deictic "I" serves to present the speaker's personality in a positive way. For exemple:

Je veux que les technologies de l'énergie deviennent un volet essentiel de la grande politique.

"I wish power technologies to become the main direction of politics".

Using the abovementioned deictic the politician underlines that he is aware of the issue and is sure in his own capability to solve the problem. Thus he is eager to present himself as a strong personality, who is ready to overcome all difficulties and complexities. For example, he says:

Je ne méconnaissais pas ces difficultés; C'est un combat que je mène sans relâche dans toutes les instances.

"I am aware of all these complexity"; "This is an uncompromising struggle which I carry out at all instances".

As we have already mentioned the personal pronoun plural deictic "We" and the possessive pronoun plural deictic "Our" are intensively used in Jacques Chirac's discourse instead of "I" and "My" and it enables the speaker to identify himself with the audience and to impact on their emotions. Thus by using the personal pronoun plural deictic "we" the politician considers the government, population and the current audience as a whole body. Thanks to this method Jacques Chirac tries to earn more respect and trust from people and show them that he, as a future President is ready to lead the country together with them. He says:

Ni les lenteurs, ni les dangers ne doivent nous décourager d'agir.

"Neither slowness nor any danger should hamper us in our activities."

C'est notre responsabilité à l'égard de nos enfants.

"This is our responsibility for our children."

L'Environnement est l'une des grandes exigences de notre temps.

"Protection of environment is one of our main demands."

Nous savons que notre santé peut se trouver affectée par des expérimentations délirantes.

"We know that our health could be damaged in result of some unreasonable experiments."

Nicolas Sarkozy on opposite, mostly uses the first person pronoun singular deictic "I" (90\%), through which he informs the population that he is aware of negative sides and the mistakes made by the of the government. Thus Sarkozy wants to convince his citizens in necessity of fulfillment of his presidential program. He attempts to persuade 
the audience that he is an authority on the subject and his future plans are trustworthy and presents himself as a strong, competent, reliable and serious leader, who should be elected by the citizens of France. He says:

Je veux tout assumer. Rien, ni personne ne m'en fera dévier.

"I am ready to take the responsibility; nobody is able to make me sour the road."

...C'est pour cela que dans cette campagne je veux parler à tous les Français.

". . . That is why I wish to talk to each French man during my campaign."

Je veux vous dire combien je suis heureux de me retrouver une fois de plus parmi vous.

"I am happy I am standing next to you."

Je souhaite une véritable révolution des mentalités.

"I am fighting for the mental revolution."

Sarkozy almost never uses the first person pronoun plural deictic "we" and he uses indefinite pronoun "on" only twice under which he means the activity of his team:

Pour la première fois depuis 30 ans, on parle de morale dans une campagne électorale.

"For the first time during the last 30 years I am speaking about the morality of some election campaigns ..."

We can say as well that comparing with Jacques Chirac Nicolas Sarkozy is often using the possessive pronoun singular deictic "my" while the possessive pronoun plural deictic "our" is not used by him in his discourse at all. Thus he once again underlines the superiority of his personality. He says:

C'est ma conception. "It is my concept".

Ma conviction est qu'un homme politique responsable est toujours du côté des victimes et qu'un homme politique qui prend le parti des délinquants est un irresponsable.

"To my opinion, responsible politician almost always stands next to victims, but the politician who stand next to the criminals in irresponsible."

All forms of auto-dialogue (the term "autodialogisme" belongs to the French Linguist Jacques Bres) when author conducts dialogue with his own words is conveying Ethos and underlines the strength of the author and sense of his responsibility:

Je l'ai dit a la jeunesse. "I told it to the young generation".

Je le dis comme je le pense. "I say it as I understand it".

It should be mentioned that in their discourses Jacques Chirac and Nicolas Sarkozy mostly use linguistic strategies, which emotionally appeal towards the audience. It indicates that they use argumentative Pathos as well. As we have mentioned above Pathos is important for carrying out successful argumentation and for impacting the audience by appealing to its emotions. Emotional appeal can effectively be used to enhance an argument in political discourses. According to Walton: "Emotional appeal is legal and it has an important role in persuasive dialogues." (Walton, 1992, p. 1)

The references made by Jacques Chirac and Nicolas Sarkozy do indicate on existing of Pathos in their discourses:

Monsieur le maire, monsieur le président du conseil régional, mes chers amis.

"Mr. Mayor, Mr. Regional Council President, My dear friends ..." (Chirac).

Mes chers amis. "My dear friends ..." (Sarkozy).

Such forms of references used at the beginning of discourse is addressed to the audience and they attract their attention from the very beginning as orators underline their immediate relationship with people. It is a remarkable fact that emotional phrases emotionally affect audience. From the very beginning of his discourse Jacques Chirac pronounces the phrases, such as:

Dans cette magnifique région d'Avranches ... comment ne pas éprouver fortement un sentiment de responsabilité? Responsabilité à l'égard de notre patrimoine historique et culturel?

"In Afghan, in such a beautiful region ... how it may happen, not to feel strong responsibility which we need to take for protecting our historical and cultural heritage."

Nous avons le sens dess respnsabilites. "We have the sense of responsibility".

In the discourses of Chirac and Sarkozy it is characteristic to find one and the same words used several times that add to some of the concepts more dearness and cogency and makes more memorable for the audience. They are: environment, the noun is used by one of the orators 18 times; and - responsibility - the abstract noun used about eight times. They also use one and the same word combination in different phrases:

$C$ 'est un projet pour l'homme. "This is the project designed for people."

$C$ 'est un projet de protection . "This is the project for protection."

$C$ 'est un projet de progress. "This is the project for progress."

$C$ 'est un projet de liberté."This is the project for freedom."

$C$ 'est un projet de responsabilité."This is the project for responsibility."

Nicolas Sarkozy is often using parallel constructions as well, or in other words he repeats one and the same words and phrases:

Je veux redonner à tous les Français la fierté d'être Français.

"I wish to return to each French man the sense of pride that they are French." 
Je veux leur dire qu'ils auront à choisir entre ceux qui ne veulent plus entendre parler de la Nation et ceux qui veulent qu'on la respecte.

"I wish to tell them they will be able to make choice between those who do not want to speak about nationality any more but who want to appraise them at their true worth".

Je veux que la France reconnaisse sa dette.

"I wish France to acknowledge its obligations."

Je veux qu'on respecte la Nation.

"I wish each of us to respect the nation".

By using such methods orators present their positions and stress basic issues and values which are urgent for the epoch. As Perelman says: "Repetition is a stylistic figure aiming at aggravation of feelings that is very important for argumentation" (Perelman, 2000, p.236). According to Amossy "Correct selection of words adds some weight to argumentation. Despite the feeling that the words are less important and/or unnoticed they are always addressed to a target group and one needs to put it in within the interactive frame" (Amossy, 2000, p.144).

Sarkozy often appeals to comparisons for emotional impact on population. In other wards based on actual data, related to the existing situation in his country he negatively characterizes almost all his opponents and talks about his advantages against them:

Il n'y a pas une histoire de France de droite et une histoire de France de gauche comme le croient le Parti socialiste et le parti Communiste.

"There is no Right French history and Left French History as the Socialist and Communist Parties think. .."

Le Président de la République ce n'est pas le chef d'un parti, même s'il est issu d'un parti. Ce n'est pas le chef d'une majorité, même s'il y a une majorité présidentielle. Ce n'est pas le Président de la droite, de la gauche ou du centre.

"President of Republic is not a leader of a party, despite the fact which party he represents. He is not the leader of majority despite the fact that there is a parliament majority in there. He cannot be the President of Rights, Leftists or Centrists only."

Le Président de la République c'est le Président de tous les Français.

"The President of France is the President of all French people".

In his discourse Sarkozy often uses the stylistic technique which directly appeal to emotions and feelings of an audience. According to Amossy "The main goal of Rhetoric is to affect feelings or persuasion purposes and each stylistic unit may affect in some way" (Amossy, 2000, p.144). In Sarkozy's discourse we mostly come across the stylistic technique, such as: Citing, Allusion, Irony.

Thus when the Sarkozy addresses young generation he cites the words of Antigone (Sophocles). By using this technique he attempts to enhance emotionality and trustworthiness to his speech. According to Perelman "Citing is a figure (unit) of communication (figure de communion), thanks to which orator brings proofs from respectful persons to enhance his own position; to impact on reader's (listener's) emotions and to share their feelings (Perelman, 2000, p. 240).” Sarkozy says:

Quand il n'y aura plus qu'une toute petite partie de la jeunesse qui comprendra ce qui signifie la phrase d'Antigone: " je ne suis pas venue pour partager la haine, mais pour partager l'amour"», nous n'aurons pas préparé une société de l'amour mais une société de la haine.

"If only a small part of young generation hears the words of Antigone - "I came here to share love but not hatred" then we will get abhorrence society instead of loving society".

We come across allusion in Sarkozy's discourse as well. According to Perelman allusion is a figure of communication as well: "We come across the allusion when the interpretation might be incomplete in case if we did not know the referent to which the author indicates without naming him/her; It could be any event which took place in the past or a cultural fact, which is kknown for the group of people with whom the author strives to share information with" (Perelman, 2000, p.239). For example:

Je veux leur dire que le 22 avril et le 6 mai, ils auront à choisir entre ceux qui ne veulent plus entendre parler de la Nation et ceux qui veulent qu'on la respecte.

"I would like to tell them that on April 22 and May 6 they should make a choice between them who do not wish to talk about nation and who wish to respect nation".

Je veux dire aux Français que le 22 avril et le 6 mai, ils auront à choisir entre ceux qui sont attachés à l'identité nationale et qui veulent la défendre et ceux qui pensent que la France a si peu d'existence qu'elle n'a même pas d'identité.

"I would like to tell French people that on April 22 and May 6 they should make a choice between those, first, who values the national identity and wishes to protect it and the second, who think that France has a short life and it has no identity."

Thus the orator indirectly indicates to the opponent parties, underlines their negative sides and at the same time he indirectly mentions his own team and estimates them in a positive way.

Nicolas Sarkozy appeals to Irony a lot that is called as a trope in Rhetoric. This is a technique used by an author to say the opposite of what he wishes to be heard by the addressees (Charaudeau, P. \& D. Mainguaneau, 2002, p. 330). For example, Sarkozy says the following: 
Voilà ce que j'appelle la faillite morale d'une certaine gauche!

"This is what I call moral failure of certain Leftists".

"Une certain gauche" - Certain Leftists - This is how Sarkozy nominates the opponent party in the following several parallel syntax constructions and that way he diminishes the meaning of their activities.

As to the rhetoric question, Sarkozy successfully appeals to it in his discourse. For example:

Quels éducateurs serons-nous si nous nous laissons aller à ces petites lâchetés? si nous apprenons à nos enfants que l'âge excuse tout?

"What kind of educators we are if we do not forbid the young generation to conduct those minor mean behaviors? Are we going to teach the youngsters that they are forgiven due to their age in any case whatever they do?"

We see that Nicolas Sarokozy expresses regret towards the situation which dominates in the country and against which he fights. He addresses people and demands for the corresponding reaction from them. It is a way of certain anticipation in people's reaction and the attempt to impacting on them. According to Meyer "Rhetoric question always considers both, the one who asks the question and who answers the question. In other words it is just a question; while asking such question we quest the image, social differences, the issue of inappropriate attitude towards the own and others' emotions." (Meyer, 200, p.129).

In result of the research in both discourses we found the values usage of which appeal to the reader's (listener's) Pathos. According to Meyer "Values are emotions (or principles) without any subject aspects" (Meyer, 2009, p.4). We need to mention the fact that Michel Meyer's works showed the meaning of emotion and its role in argumentation.

The discourses selected by us both candidates attempt to use the words and phrases expressing such concepts, which is a common value for the society. Famous linguist Philippe Breton believes that: "Appealing to values that is one of the most important ways for argumentation, mobilizes emotions and affects deeply" (Breton, 2000, p.78).

Pretty often orator does his/her best by conveying those values and elements, which she/he bases on, to present them in a way to make the acceptable for everyone. Thus "the statement of values appeal to personal emotions and the stamen of fact appeals to values." (Perelman, 2000, p.236).

The selected politicians convey their discourse in different time period, 2002 (Chirac) and 2007 (Sarkozy). Correspondingly the values differ according to the epochs. As we have mentioned Jacques Chirac values the most environment and problems related ecology all over the world. He conveys real facts and describes all activities and situation, which is urgent to be addressed in the indicated period. He states that the existing problems in that direction may negatively affect France and the whole world in general.

Here we need to note that Jacques Chirac often mentions common and collective values that indicate to the unity and close relation with people which at the same time conveys Pathos. In his discourse the presidential candidate expresses dissatisfaction related to many issues existing in the world in general and sates that it is necessary to provide changes everywhere. He says:

C'est l'efficacité et la responsabilité collective.

"It is effectiveness and collective responsibility".

Ce sont ces principes, ces valeurs qu'ensemble nous allons faire gagner demain.

"These are the principles and values, which we need to win tomorrow".

For Nicolas Sarkozy French republic, people and identity are the most important values. Almost in each paragraph of his speech Sarkozy stresses on abovementioned concepts. He directs the whole discourse to the issues faced by French people and to his future plans for solution of those issues. By doing it Sarkozy strives to deepen the electorate's love towards the motherland and to show that his main task is to care about France.

Je crois à l'identité de la France qui est faite de principes et de valeurs qui se sont forgées au cours d'une très longue histoire.

"I believe in identity of France that is comprised of principles and values"

Je souhaite qu'on ne puisse pas vivre durablement en France, sans savoir parler et écrire le français.

"I would wish that those who do not speak and write in French language could not stay in France for long".

Thus as the corpus we have researched showed that both presidential candidates endeavor conveying common values and impacting on people's emotions to earn their trust and faith to be supported during elections by them.

\section{CONCLUSION}

In conclusion we should say that in the political discourses of Jacques Chirac and Nicolas Sarkozy we attempted to reveal all those linguistic markers and means, which serve to express the Triad of Argumentation: Logos, Ethos and Pathos. Thanks to the Triad the discourses become more argumentative and it is very important for understanding messages and impacting on audience.

We found out that both political discourse are logically constructed and ideologically correct. We should also note that both candidates use one and the same linguistic means for presenting themselves. By using personal and possessive pronoun deictic they reveal their Ethos, but Nicolas Sarkozy appeals to those elements more often. As to the Pathos or in other words, emotional appeals, the difference is that Jacques Chirac, mostly conveys phrases expressing emotions, addresses, repetitions and stresses on values, but Nicolas Sarkozy in addition to all abovementioned appeals to comparison and to some stylistic techniques as well. 
It needs to be noted that the discourses analyzed by us were successful for both of them, Jacques Chirac won in 2002 and Nicolas Sarkozy won in 2007 in the presidential elections in France. Both of them had achieved the goals successfully during their discourses.

In future studies we plan to compare pre-election campaign discourses of Nicolas Sarkozy and Francois Oland carried out in 2012 as we suppose that to analyze political discourse of the same period will be even more interesting.

\section{REFERENCES}

[1] Aristotle. (1981). Rhetoric. Traduction Kukava, T. Tbilisi: TSU.

[2] Adam , J-M. (2011) . Argumentation publicitaire. Armand Colin.

[3] Amossy, R. (2000). L'Argumentation dans le discours. Paris : Nathan Univrtsité.

[4] Amossy, R. ( 1999). L'image de soi dans le discours. La construction de l'ethos. Genève: Delachaux et Niestlé.

[5] Breton, Ph. (2000). La parole manipulée. Paris : La découverte.

[6] Cabasino, F.(2009). La construction de l'ethos présidentiel dans le débat télévisé français. in Mots. \#89 Les langages du politique. Paris : aad.revues.org.

[7] Charaudeau, P. \& D. Mainguaineau. (2002). Dictionnaire d'analyse du discours. Paris: Seuil.

[8] Charaudeau, P. (2004).Comment le langage se noue à l'action dans un modèle socio-communicationnel du discours. De l'action au pouvoir. in Cahier de linguistique francaise. № 26.Paris. P. 151-175.

[9] Charaudeau, P. (2005). Le discours politique. Les masques du pouvoir. Paris: Vuibert.

[10] Dokhturishvili, M. (2005). Argumentation, such as a phenomenon and a concept in old and new rhetoric. In language and culture. \# 2. Tbilisi.

[11] Ducrot ,O. (1980). Les échelles argumentatives. Paris : Minuit.

[12] Maingueneau, D.(1993). Le contexte de l'œuvre littéraire. Enonciation, écrivain, société. Paris : Seuil.

[13] Maingueneau, D. (2006). Analyse des textes de communication. Paris : Armand Colin. pp. 20-23.

[14] Meyer, M. (2009). Comment repenser le rapport de la rhétorique et de l'argumentation? in Argumentation et Analyse du Discours. №2 Rhétorique et argumentation. aad.revues.org.

[15] Meyer, M. (2004). Le renouveau de la rhétorique. Presses Universitaires de France. Collection dirigée par Yves Charles Zarka.

[16] Meyer, M. (1996).Questions de rhétorique. Langage, raison et séduction. Paris : Le livre de poche.

[17] Perelman, C. \& Titeca, O. (2000).Traité de l'argumentation. La nouvelle rhétorique. Bruxelles: Edition de l’Université de Bruxelles.

[18] Plantin, C. (2009). Un lieu pour les figures dans la théorie de l'argumentation. in Argumentation et Analyse du Discours. №2 Rhétorique et argumentation. aad.revues.org.

[19] Walton, D. (1992). The place of emotion in argument. The Pensylvania state University press.

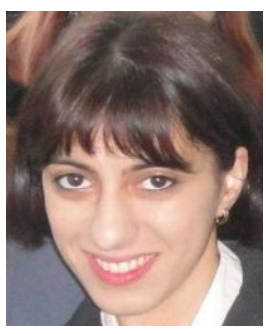

Tamar Mshvenieradze was born in 1982 in Rustavi (Georgia). In 2004 she completed Bachelor's degree in Linguistics of the joint study program "French as a foreign language and applied foreign languages" established by the University Paul-Valéry Montpellier 3 (France) and the Ila Chavchavadze Tbilisi State University of Language and Culture (Georgia). In 2007 she was awarded Master's degree in Linguistics by the University Paul-Valéry Montpellier 3 (France). In the years 2008-2009 she worked as a teacher of French on the abovementioned study program. In June2012, as a participant of Tempus project, she attended classes at the University Paris-Est (Paris, France) in order to extend her thesis research. In May 2013 she took part in the international Conference "Language and Culture in the era of Globalization" (Chisinau, Moldova). Actually, she is a doctoral student and a researcher at the faculty of Arts and Sciences of Ilia State University (Tbilisi, Georgia) and is working on her PhD thesis in the field of discourse analysis. 